\title{
Biological Markers of Undernutrition and Risk of Complications in Children Hospitalized at the Teaching Hospital of Brazzaville
}

\author{
Christel Mikolélé-Bilombo1, Lucie Charlotte Atipo-Ibara Ollandzobo1,2, \\ Steve Vassili Missambou Mandilou ${ }^{2 *}$, Thibaut Ocko Gokaba Lethso1, \\ Clausina Mikolélé-Bilombo Ahoui ${ }^{1,3}$, Josué Simo Louokdom4, Martial Landry Miguel, \\ Etienne Mokondjimobe1, Donatien Moukassa1, Jean Robert Mabiala-Babela1,2, \\ Ange Antoine Abena1,5, Jean-Rosaire Ibara1,3 \\ ${ }^{1}$ Faculty of Health Sciences, Marien Ngouabi University, Brazzaville, Congo \\ ${ }^{2}$ Department of Pediatrics, Teaching Hospital of Brazzaville, Brazzaville, Congo \\ ${ }^{3}$ Department of Gastroenterology and Hepatology, Teaching Hospital of Brazzaville, Brazzaville, Congo \\ ${ }^{4}$ Cameroon Mountain University, Douala, Cameroon \\ ${ }^{5}$ Denis Sassou Nguesso University, Brazzaville, Congo \\ Email: ^mstevevassili@yahoo.fr
}

How to cite this paper: Mikolélé-Bilombo, C., Ollandzobo, L.C.A.-I., Mandilou, S.V.M., Lethso, T.O.G., Ahoui, C.M.-B., Louokdom, J.S., Miguel, M.L., Mokondjimobe, E., Moukassa, D., Mabiala-Babela, J.R., Abena, A.A. and Ibara, J.-R. (2022) Biological Markers of Undernutrition and Risk of Complications in Children Hospitalized at the Teaching Hospital of Brazzaville. Journal of Biosciences and Medicines, 10, 1-9. https://doi.org/10.4236/jbm.2022.102001

Received: December 2, 2021

Accepted: January 27, 2022

Published: January 30, 2022

Copyright (c) 2022 by author(s) and Scientific Research Publishing Inc. This work is licensed under the Creative Commons Attribution International License (CC BY 4.0).

http://creativecommons.org/licenses/by/4.0/

\begin{abstract}
Introduction: Undernutrition is a condition frequently encountered in pediatrics. It leads to an increased morbidity and mortality regardless of the underlying condition or other risk factors such as age. In countries with limited resources such as ours, the diagnosis of undernutrition is often limited to the clinical presentation, and the contribution of biology is not often taken into account. Objectives: To establish the relationship between anthropometric parameters and biological markers in the diagnosis and classification of undernutrition and to assess the risk of infectious complications during undernutrition in children. Materials and Methods: A cross-sectional study conducted in Brazzaville among undernourished children aged 1 - 59 months between October 2018 and April 2019. Clinical diagnosis was based on WHO growth charts. The CRP, orosomucoid, albumin and transthyretin were obtained using the Cobas c311 analyzer, which enabled the calculation of Prognostic Inflammatory and Nutritional Index (PINI). The comparison of the means of the biological markers used the Student's t-test, the risk of infectious complications the chi-square. The correlation of the diagnostic value of Z-score weight/height and PINI was also investigated. The significance level was set at 0.05 . Results: Of the 95 children enrolled 63 (66.3\%) were clinically severely malnourished, including 26 acute (41.3\%) and 37 chronic (58.7\%). The PINI revealed severe undernutrition in 85 children (89.4\%) including 50
\end{abstract}


acute $(58.8 \%)$ and 35 chronic (41.2\%). CRP and orosomucoid were statistically higher in severe acute undernutrition ( $\mathrm{p}<0.001$ ). Serum albumin levels varied between severe and non-severe undernutrition only in the acute form $(\mathrm{p}<0.001)$; transthyretin was decreased to a lesser degree $(\mathrm{p}<0.05)$ in both forms of undernutrition. All children with severe undernutrition were at risk of infectious complications ( $\mathrm{p}<0.05$ ). PINI had a positive predictive value for the detection of severe undernutrition of $87 \%$. Conclusion: Anthropometric parameters have a front-line advantage for assessing and classifying undernutrition. However, biological markers of undernutrition with PINI should be systematized in the diagnosis and management of undernutrition.

\section{Keywords}

Undernutrition, Nutritional Marker, Inflammatory Marker, PINI, Child, Congo

\section{Introduction}

Undernutrition is a condition frequently encountered in pediatrics, there are two forms, acute and chronic. The first is growing rapidly and reflects the current situation of acute food deficiency. While chronic undernutrition is distinguished by its slower evolution which results from undernourishment extending over a longer period [1].

Two mechanisms preside over the occurrence of undernutrition, "exogenous" undernutrition, which is a pure form, without inflammatory pathology, caused by a defect in exogenous food intake (deficiency of intake, malabsorption, anorexia nervosa); in this situation, the body adapts by decreasing the hepatic synthesis of nutritional proteins: albumin, transferrin, prealbumin, Retinol Binding Protein (RBP), somatomedin C or IGF 1; “endogenous" undernutrition, a mechanism known in chronic pathologies, infectious or not, during which undernutrition and inflammation are associated; in this case, the increase in inflammation proteins (reactive protein $\mathrm{C}$, orosomucoid, etc.), stimulated by cytokines (Il6, TNF- $\alpha$ ) comes at the expense of nutritional proteins (albumin, prealbumin, IGF-1) [2] [3]. Whatever the mechanism, undernutrition leads to an increase in morbidity and mortality regardless of the underlying pathology or other risk factors such as age [4]. Moreover, any child with severe undernutrition should be considered, until proven otherwise, as infected. Thus, the basic nutritional protein profile combines two nutrition proteins (prealbumin and albumin) and an inflammation protein (orosomucoid). The association with these proteins of the C-reactive protein (CRP) completes the inflammatory profile frequently associated with undernutrition [2] [3]. During undernutrition, the almost frequent association of the infection requires a systematic evaluation of the nutritional status coupled with the inflammatory status. Moreover, a prognostic index was proposed by Ingenbleek and Carpentier in 1985, the PINI (Prognostic Inflam- 
matory and Nutritional Index), grouping two proteins sensitive to variations in nutritional status: albumin (ALB), prealbumin (PAB) or transthyretin (TTR), and two proteins representative of inflammation: the orosomucoid (ORO) and the C-reactive protein $(\mathrm{CRP}): \mathrm{PINI}=\mathrm{ORO}(\mathrm{mg} / \mathrm{l}) \times \mathrm{CRP}(\mathrm{mg} / \mathrm{l}) / \mathrm{ALB}(\mathrm{g} / \mathrm{l}) \times \mathrm{PAB}$ $(\mathrm{mg} / \mathrm{l})[5]$.

The interpretation of this index is as follows:

- $\leq 1$ : uninfected and undernourished patients;

- 1 to 10 : low risk of mortality;

- 11 to 20: moderate risk;

- 21 to 30: high risk;

- >31: significant risk of mortality (vital risk).

Thus, in clinical practice, the evaluation of the nutritional state must always include a clinical part, based on anthropometric measurements, supplemented by a biological investigation, in particular of the proteins of nutrition and inflammation. In this study we are interested in the biological markers proper of undernutrition validated by several studies [6] [7] in order to establish the relation between anthropometric parameters and biological markers during undernutrition and to evaluate the risk of infectious complications during undernutrition in hospitalized children.

\section{Patients and Methods}

This is a descriptive and analytical cross-sectional study carried out at the Teaching Hospital of Brazzaville between October 2018 and April 2019. The enrollment of children was done in the department of pediatrics, and the laboratory investigations at the National Reference Center of sickle cell anemia. During the study period, 601 children were admitted, among whom 95 had undernutrition. We included all children aged between one and 59 months, clinically undernourished and whose parents or guardians agreed to participate in the study. Children with hematological pathologies that could disrupt the inflammatory profile and those whose parents or guardians did not agree to participate were not included. This study was carried out after obtaining the approval of the Health Sciences Research Ethics Committee of Congo

( $\mathrm{n}^{\circ}$ 169/MRSIT/IRSSA/CERSSA).

For all children, the socio-demographic and anthropometric characteristics (gender, age, birth weight, weight at the time of the survey, the height, the head circumference, mid-upper arm circumference, WHO Z-scores weight for age, weight for height, height for age, presence or not of edema and associated diagnosis) were collected from the medical records. On the other hand, a sample of four milliliters of blood was taken in a dry tube in order to carry out biological examinations (including CRP, Orosomucoid, Albumin, Transthyretin or pre-albumin). The collected blood underwent a biological assay using a Cobas c311 analyzer from Roche/Hitachi, which is a system software controlled and fully automated for photometric assays and ion selective electrode measurements. The 95 children were divided into two groups, based on both clinical presentation and labor- 
atory findings. Depending on the clinic presentation of undernutrition, the first group included children with moderate undernutrition (WHO child growth standards Weight/Height ratio between -2 and $-3 \mathrm{Z}$-scores) and the second one those with severe undernutrition (WHO child growth standards Weight/Height ration $<-3 \mathrm{Z}$-scores). Depending on the laboratory findings, the first group included children without any at risk of developing complications (PINI $<1$ ) and the second one those who were at risk of developing complications (PINI $>1$ ).

The database was designed using Excel software and the statistical analysis performed using R (Core Team) 3.5.3 software. 2019. The categorical variables were presented in the form of frequency or number ( $\mathrm{N}$ and $\mathrm{n}$ ) and proportions (\%). The study of the profile of biological markers during undernutrition used Student's t-test. The assessment of the risk of infectious complications by PINI during undernutrition required the application of the chi-square test. The correlation of the diagnostic value of the Weight/Height Z-score and of the PINI was also studied. In all cases, the significance threshold was set at 0.05 .

\section{Results}

Of the 95 children who were the subjects of this study, 47 (49.5\%) were boys, representing a Male/Female ratio of 1 ; the mean age was $14.7 \pm 10.8$ months ( 1 to 59 months). It was acute malnutrition (AM) in 55 cases (57.9\%), and chronic (CM) in 40 cases (42.1\%). The mean height for all included children was $70.1 \pm$ $9.96 \mathrm{~cm}$; it was $69.6 \pm 11 \mathrm{~cm}$ among children with severe malnutrition. According to the clinical nutritional index, the children were found to have severe malnutrition in 63 cases (66.3\%) including 26 acute cases (41.3\%) and 37 chronic cases (58.7\%). The other clinical characteristics of the study subjects are shown in $\mathrm{Ta}-$ ble 1. According to the inflammatory index, severe undernutrition affected 85 children (89.4\%), including 50 acute (58.8\%) and 35 chronic (41.2\%). Concerning the biological markers (Table 2), we found that during acute undernutrition, the proteins of inflammation (CRP and Orosomucoid) and that of nutrition (ALB and TTR) had a statistically link with severe undernutrition $(\mathrm{p}<0.001)$. Concerning the chronic undernutrition, the CRP, the Orosomucoid $(\mathrm{p}<0.001)$ and the TTR $(\mathrm{p}<0.05)$ also showed a statistical link. Therefore, the albumin $(\mathrm{p}>$ 0.05) did not show a link with chronic undernutrition. The analysis of Table 3 shows for the PINI < 1 (which means the lack of the risk of developing infectious complications), and regardless of the type of malnutrition (acute or chronic), only children with moderate undernutrition were involved. On the other hand, for the PINI score $>1$ (which means the risk of developing infectious complications), all children with severe undernutrition were affected ( $p<0.05)$. The sensibility of the $\mathrm{z}$-scores on the PINI score is noted in Table 4 and corresponds to 0.42 which means that the $\mathrm{z}$-scores had only a $42 \%$ chance of detecting children who were truly severely malnourished as reported by PINI, and therefore were not very sensitive. In the same way, the z-score has only a $50 \%$ chance $(0.50)$ of detecting truly moderately malnourished children reported by PINI, and is there- 
fore not very specific. It is also noted that the PINI score has a positive predictive value of 0.87 , i.e. $87 \%$ chance that children declared severely malnourished by the $\mathrm{z}$-scores are also malnourished by the PINI. Its negative predictive value is 0.1 , i.e. only a $10 \%$ chance that children declared moderately malnourished by the z-scores are also malnourished by the PINI.

Table 1. Characteristics of the subjects of study.

\begin{tabular}{|c|c|c|c|c|c|}
\hline & Total & Moderate undernutrition & Severe undernutrition & \multirow{3}{*}{ O.R. [IC 95\%] } & \multirow{3}{*}{$\mathrm{P}$} \\
\hline & $\mathrm{n}=95(100 \%)$ & $\mathrm{n}=32(33.7 \%)$ & $\mathrm{n}=63(66.3 \%)$ & & \\
\hline & Mean \pm SD & Mean \pm SD & Mean \pm SD & & \\
\hline Age (months) & $14.7 \pm 10.8$ & $13.4 \pm 7.41$ & $15.3 \pm 12.2$ & $1.02[0.97-1.06]$ & 0.346 \\
\hline Birth weight $(\mathrm{g})$ & $2936 \pm 582$ & $2992 \pm 569$ & $2908 \pm 591$ & $1.00[1.00-1.00]$ & 0.57 \\
\hline Weight survey (Kg) & $6.59 \pm 1.93$ & $7.54 \pm 1.46$ & $6.09 \pm 1.96$ & $0.61[0.46-0.82]$ & $<0.001$ \\
\hline Height or Size $(\mathrm{cm})$ & $70.1 \pm 9.96$ & $70.9 \pm 7.60$ & $69.6 \pm 11.0$ & $0.99[0.71-0.98]$ & 0.496 \\
\hline Head circumference $(\mathrm{cm})$ & $43.3 \pm 3.15$ & $44.4 \pm 2.37$ & $42.8 \pm 3.37$ & $0.83[0.71-0.98]$ & 0.01 \\
\hline MUAC $(\mathrm{cm})$ & $11.8 \pm 1.83$ & $12.9 \pm 1.27$ & $11.2 \pm 1.82$ & $0.48[0.32-0.70]$ & $<0.001$ \\
\hline Acute undernutrition & $55(57.9 \%)$ & $29(90.6 \%)$ & $26(41.3 \%)$ & & \\
\hline Chronic undernutrition & $40(42.1 \%)$ & $3(9.38 \%)$ & $37(58.7 \%)$ & $13.8[3.78-50.0]$ & $<0.001$ \\
\hline
\end{tabular}

Table 2. Profile of biological markers during undernutrition.

\begin{tabular}{cccccc}
\hline & & CRP & Orosomucoid & Albumin & Transthyretin \\
\cline { 3 - 6 } & & $<5 \mathrm{mg} / \mathrm{l}$ & {$[500-1200 \mathrm{mg} / \mathrm{l}]$} & {$[35-50 \mathrm{~g} / \mathrm{l}]$} & {$[200-350 \mathrm{mg} / \mathrm{l}$} \\
\cline { 3 - 6 } & & Mean $\pm \mathrm{SD}$ & Mean $\pm \mathrm{SD}$ & Mean $\pm \mathrm{SD}$ & $\mathrm{Mean} \pm \mathrm{SD}$ \\
\hline Acute undernutrition & Moderate $\mathrm{n}=5(9 \%)$ & $5.00 \pm 0.00$ & $970 \pm 164$ & $42.2 \pm 2.53$ & $228 \pm 88.7$ \\
$\mathrm{n}=55(57.9 \%)$ & Severe $\mathrm{n}=50(91 \%)$ & $33.4 \pm 42.2^{\star * *}$ & $2084 \pm 741^{\star * *}$ & $31.6 \pm 7.89^{* * *}$ & $119 \pm 53.8^{\star}$ \\
Chronic undernutrition & Moderate $\mathrm{n}=5(12.5 \%)$ & $5.60 \pm 1.34$ & $804 \pm 339$ & $35.0 \pm 13.1$ & $180 \pm 30.8$ \\
$\mathrm{n}=40(42.1 \%)$ & Severe $\mathrm{n}=35(87.5 \%)$ & $38.5 \pm 41.0^{* * *}$ & $2323 \pm 638^{* * *}$ & $29.1 \pm 7.03$ & $124 \pm 67.3^{*}$ \\
\hline
\end{tabular}

${ }^{*} \mathrm{p}<0.05 ;{ }^{* * *} \mathrm{p}<0.001$.

Table 3. Relation between undernutrition and risk of infectious complications.

\begin{tabular}{cccccccc}
\hline & & PINI $<1$ & PINI [1 - 10] & PINI [11 - 20] PINI [21 - 30] & PINI > 31 \\
\cline { 3 - 7 } & & No risk & Low risk & Moderate risk & High risk & Vital risk \\
\cline { 3 - 7 } & & $\mathrm{n}=10(10.5 \%)$ & $\mathrm{n}=44(28.1 \%)$ & $\mathrm{n}=7(7.3 \%)$ & $\mathrm{n}=7(7.3 \%)$ & $\mathrm{n}=27(28.4 \%)$ \\
\hline Acute undernutrition & Moderate $\mathrm{n}=5(9 \%)$ & $5(100 \%)$ & $0(0.00 \%)$ & $0(0.00 \%)$ & $0(0.00 \%)$ & $0(0.00 \%)$ \\
$\mathrm{n}=55(57.9 \%)$ & Severe $\mathrm{n}=50(91 \%)$ & $0(0.00 \%)$ & $28(56.0 \%)^{* * *}$ & $4(8.00 \%)^{* *}$ & $6(12.0 \%)^{* *}$ & $12(24.0 \%)^{* * *}$ \\
Chronic undernutrition & Moderate $\mathrm{n}=5(12.5 \%)$ & $5(100 \%)$ & $0(0.00 \%)$ & $0(0.00 \%)$ & $0(0.00 \%)$ & $0(0.00 \%)$ \\
$\mathrm{n}=40(42.1 \%)$ & Severe $\mathrm{n}=35(87.5 \%)$ & $0(0.00 \%)$ & $16(45.7 \%)^{* * *}$ & $3(8.57 \%)^{*}$ & $1(2.86 \%)$ & $15(42.9 \%)^{* * *}$ \\
\hline
\end{tabular}

${ }^{\star} \mathrm{p}<0.05 ;{ }^{* *} \mathrm{p}<0.01 ;{ }^{\star} \mathrm{p}<0.001$. 
Table 4. Correlation between diagnostic value of the Weight/Height ratio in Z-scores/PINI.

\begin{tabular}{|c|c|c|c|c|}
\hline & & \multicolumn{2}{|c|}{ PINI (Reference biological test) } & \\
\hline & & Severe & Moderate & \\
\hline \multirow{4}{*}{$\begin{array}{c}\text { Z-Scores } \\
\text { (Clinical test) }\end{array}$} & Severe & $A=35$ & $\mathrm{~B}=5$ & $\mathrm{PPV}=\mathrm{A} / \mathrm{A}+\mathrm{B}=35 / 45=\mathbf{0 . 8 7}$ \\
\hline & Moderate & $\mathrm{C}=50$ & $\mathrm{D}=5$ & $\mathrm{NPV}=\mathrm{D} / \mathrm{C}+\mathrm{D}=5 / 55=0.1$ \\
\hline & & Sensibility $=A / A+C$ & Specificity $=B / B+D$ & \\
\hline & & $35 / 85=0.42$ & $5 / 10=0.5$ & \\
\hline
\end{tabular}

\section{Discussion}

Anthropometric measurements retain all of their first-line diagnostic and prognostic interest, particularly in very young children [6]. Thus, the historical undernutrition index is the Waterlow index [7], which corresponds to the ratio between the child's weight and the expected weight for his height (Weight/Height). This index indicates moderate undernutrition (Weight/Height $70 \%-80 \%$ ) or severe (Weight/Height $<70 \%$ ) undernutrition. The body mass index (BMI) obtained using the Quetelet equation (ratio of the weight in kilograms over the size squared) for some authors has a good correlation with the Waterlow index [8] [9]. In infants, the mid-upper arm circumference (MUAC) to head circumference $(\mathrm{HC})[\mathrm{MUAC} / \mathrm{PC}]$ ratio has a good value for evaluating nutritional status as well [10] [11]. Currently, the WHO child growth standards are used and are suitable for all children regardless of their origin [12].

Weight loss during undernutrition can be rapid resulting in acute undernutrition (wasting), or slow resulting in chronic undernutrition or stunting. The evaluation of undernutrition in clinical practice must include a clinical and paraclinical component. The latter essentially involve the determination of serum proteins for undernutrition and inflammation. Table 2 shows the serum disturbances of the proteins of inflammation and undernutrition according to the two forms of undernutrition. Serum concentrations of CRP and Orosomucoid are significantly increased in both forms of undernutrition $(\mathrm{p}<0.001)$. The significant increase in these two markers testifies the existence, during severe undernutrition, of an inflammatory state. These results can be compared with those of Monnet et al. in 1997 who found a CRP of $6.44 \mathrm{mg} / \mathrm{l}$ in children without malnutrition and 21.89 in malnourished [13], and the orosomucoid of $870 \mathrm{mg} / \mathrm{l}$ in children without malnutrition and $2080 \mathrm{mg} / \mathrm{l}$ in malnourished subjects. This findings corroborate the thesis that a child with severe undernutrition must be considered, until proven otherwise, as infected and must be systematically treated as such, even in the absence of obvious signs of infections [14] [15]. Serum disturbances in markers of undernutrition are observed with, however, a statistically different profile between albumin and transthyretin when comparing children with severe undernutrition to those with moderate undernutrition. TTR is the best marker for the early diagnosis of acute undernutrition and the monitoring of nutritional management compared to albumin, because of its specificity and its short half-life 
of 48 hours [16]. Thus, its measurement is essential during the follow-up of severe undernutrition to assess the effectiveness of treatment. The assessment of TTR must be coupled with the CRP assay, in order to be able to distinguish a decrease in TTR of purely nutritional or mixed origin (both nutritional and inflammatory) [17]. The highly significant decrease in serum albumin levels seen during acute undernutrition and not significant in chronic undernutrition is a witness to the progressive adaptation of the body during chronic undernutrition. Indeed, during undernutrition, mainly "exogenous", the body goes into "reductive adaptation" allowing it to adapt to the new situation of nutritional deficiency. The tendency is to balance albuminemia, the rate of which becomes close to that observed during moderate undernutrition. In fact, it is common for children with severe chronic undernutrition to have gone through severe acute undernutrition.

All children with a PINI $>1$ therefore at risk of developing infectious complications had severe undernutrition, acute or chronic. Hence the propensity to systematically put severely malnourished children on antibiotics, the route of administration will depend on the clinical picture. However, children with a PINI > 20 should be constantly monitored in a specialized unit because of the life-threatening outcome which is often encounted. In view of the results in $\mathrm{Ta}$ ble 3, it can be suggested that severely undernourished children necessarily have a PINI score $>1$. There is therefore a correlation between PINI $>1$ and severe undernutrition. Thus, according to the results of Table 4, the sensibility of the $\mathrm{z}$-scores on the PINI score corresponds to 0.42 which means that the $\mathrm{z}$-scores had only a $42 \%$ chance of detecting children who were truly severely malnourished as reported by PINI, and therefore were not very sensitive. In the same way, the $z$-score has only a $50 \%$ chance $(0.50)$ of detecting truly moderately malnourished children reported by PINI, and is therefore not very specific. It is also noted that the PINI score has a positive predictive value of 0.87 , i.e. $87 \%$ chance that children declared severely malnourished by the z-scores are also malnourished by the PINI. Its negative predictive value is 0.1 , i.e. only a $10 \%$ chance that children declared moderately malnourished by the $\mathrm{z}$-scores are also malnourished by the PINI. The PINI $>1$ therefore appears more specific in the positive diagnosis of severe undernutrition in cases of moderate clinical undernutrition. As a result, several children considered by the Weight/Height ratio as having moderate undernutrition may already be in the severe undernutrition state with all the risks to which it exposes. Coupling the clinical diagnosis of undernutrition (based on anthropometric measures) with the biological markers (summarized by the PINI score) can be of great importance.

This study conducted at the Teaching Hospital of Brazzaville has some limitations, especially in terms of number of center (one center) and patient recruitment as the teaching hospital is a third level health care center. This can be overcome by conducting the study with the same protocol in many other health care centers, mainly in primary ones (to enroll more patients) and in other cities 
of the country, this will makes possible to extrapolate these findings to the entire population of the country. Despite this notice, this study (the first in this category to the best of our knowledge) had shown the importance of biological markers in the assessment, the management and the follow-up of children with undernutrition.

\section{Conclusion}

The weight and the anthropometric indices which relate to it constitute the "gold standard" of the appreciation of the nutritional state. They thus keep their advantage of orientation and classification of first intention in the management of undernutrition. However, the biological markers of undernutrition distinguish the infectious and/or nutritional origin from undernutrition. In addition, the PINI, more specific in assessing the degree of severity of undernutrition should be systematized in the management for concerns of diagnostic efficiency and monitoring. This would prevent relapse or the risk of death.

\section{Acknowledgements}

We would like to thank the staff of the Pediatric Department of the Teaching Hospital of Brazzaville, as well as the staff of the Biochemistry Department of the laboratory of the National Reference Center for Sickle Cell Disease.

\section{Conflicts of Interest}

The authors declare no conflicts of interest regarding the publication of this paper.

\section{References}

[1] Mehta, N.M., Mark, R., Corkins, L.B., Malone, A., Praveen, S., Carney, L., et al. (2013) Defining Pediatric Malnutrition: A Parading Shift toward Etiology-Related Definitions. Journal of Parenteral and Enteral Nutrition, 37, 460-481. https://doi.org/10.1177/0148607113479972

[2] Bach-Ngohou, K., Bettembourg, A., Le Carrer, D., Masson, D. and Denis, M. (2004) Evaluation Clinico-Biologique de la dénutrition. Annales de Biologie Clinique, 62, 395-403.

[3] Girandet, P. (1992) Concept et intérêt clinique des profils protéiques. Revue de Bilogie Médicale, 33/188, 61-69.

[4] Cornu, A., Pondi, N.O. and Agbor, E.T. (1986) Anémie et malnutrition protéinoénergétique modérée chez l'enfant de la province du nord-Cameroun. INSERM Colloque, 136, 121-132.

[5] Ingenbleek, Y. and Carpentier, Y.A. (1985) A Prognostic Inflammatory and Nutritional Index Scoring Critically Ill Patients. International Journal for Vitamin and Nutrition Research, 55, 91-101.

[6] Goulet, O. (1996) Evaluation pratique de l'état nutritionnel. In: Ricour, C., Ghisolfi, J. and Putet, G., Eds., Goulet OTraité de nutrition pédiatrique, Edition Maloine, Paris, 453-463.

[7] Wterlow, J.C. (1972) Classification and Definition of Protein-Calorie Malnutrition. 
The BMJ, 3, 566-569. https://doi.org/10.1136/bmj.3.5826.566

[8] Mei, Z., Grummer-Strawn, L.M., Pietrobelli, A., Goulding, A., Goran, M.I. and Dietz, W.H. (2002) Validity of Body Mass Index Compared with Other Body-Composition Screening Indexes for the Assessment of Body Fatness in Children and Adolescents. The American Journal of Clinical Nutrition, 75, 978-985. https://doi.org/10.1093/ajcn/75.6.978

[9] Cole, T.J., Flegal, K.M., Nicholls, D. and Jackson, A.A. (2007) Body Mass Index Cut Offs to Define Thinness in Children and Adolescents: International Survey. The BMJ, 335, 194. https://doi.org/10.1136/bmj.39238.399444.55

[10] Myatt, M., Khara, T. and Collins, S. (2006) A Review of Methods to Detect Cases of Severely Malnourished Children in the Community for Their Admission into Community-Based Therapeutic Care Programs. Food and Nutrition Bulletin, 27, S7-S23. https://doi.org/10.1177/15648265060273S302

[11] Robillard, P.Y. (1989) Intérêt de la mesure du rapport périmètre brachial (PB)/périmètre crânien (PC) dans l'évolution du statut nutritionnel du nourrisson et du jeune enfant, in : les carences nutritionnelles dans les PVD. $3^{\text {ème }}$ journée du GERM. Katharla-ACCT Paris, 52-56.

[12] (2019) https://www.who.int/childgrowth/standards/fr/

[13] Monnet, D., Ahouty, C.P., Konan-Waidhet, D., Malan, K., Houenou, A.Y., Tebi, A., et al. (1997) Marqueurs protéiques dans les états de malnutrition chez le jeune Ivoirien âgé de moins de cinq ans. Médecine d Afrique Noire, 44, 75-78.

[14] Moraleda, C., Aguilar, R., Quintó, L., Nhampossa, T., Renom, M., Nhabomba, A., et al. (2017) Anaemia in Hospitalized Preschool Children from a Rural Area in Mozambique: A Case Control Study in Search for Aetiological Agents. BMC Pediatrics, 17, Article No. 63. https://doi.org/10.1186/s12887-017-0816-x

[15] Briend, A., Maire, B. and Desjeux, J.F. (1996) Malnutrition protéino-énergétique dans les pays en voie de développement Ricour, C., Ghisolfi, J., Putet, G. and Goulet, O., Eds., Traité de nutrition pédiatrique, Maloine, Paris, 467-512.

[16] Devoto, G., Gallo, F., Marchello, C., Racchi, O., Garbarini, R., Bonassi, S., et al. (2006) Prealbumin Serum Concentrations as a Useful Tool in the Assessment of Malnutrition in Hospitalized Patients. Clinical Chemistry, 52, 2281-2285. https://doi.org/10.1373/clinchem.2006.080366

[17] Potter, M.A. and Luxton, G. (2002) Transthyrétine Measurement as a Screening Tool for Protein Calorie Malnutrition in Emergency Hospital Admissions. Clinical Chemistry and Laboratory Medicine, 40, 1349-1354.

https://doi.org/10.1515/CCLM.2002.233 